\title{
Performance of full-scale woodchip bioreactors treating effluents from commercial RAS
}

von Ahnen, Mathis; Pedersen, Per Bovbjerg; Dalsgaard, Johanne

Published in:

Aquacultural Engineering

Link to article, DOI:

10.1016/j.aquaeng.2018.10.004

Publication date:

2018

Document Version

Peer reviewed version

Link back to DTU Orbit

Citation (APA):

von Ahnen, M., Pedersen, P. B., \& Dalsgaard, J. (2018). Performance of full-scale woodchip bioreactors treating effluents from commercial RAS. Aquacultural Engineering, 83, 130-137.

https://doi.org/10.1016/j.aquaeng.2018.10.004

\section{General rights}

Copyright and moral rights for the publications made accessible in the public portal are retained by the authors and/or other copyright owners and it is a condition of accessing publications that users recognise and abide by the legal requirements associated with these rights.

- Users may download and print one copy of any publication from the public portal for the purpose of private study or research.

- You may not further distribute the material or use it for any profit-making activity or commercial gain

- You may freely distribute the URL identifying the publication in the public portal

If you believe that this document breaches copyright please contact us providing details, and we will remove access to the work immediately and investigate your claim. 


\title{
Performance of full-scale woodchip bioreactors treating effluents from commercial RAS
}

Mathis von Ahnen, Per Bovbjerg Pedersen, Johanne Dalsgaard

Technical University of Denmark, DTU Aqua, Section for Aquaculture, The North Sea Research Centre, P.O. Box 101, DK-9850 Hirtshals, Denmark.

Corr. author email address: $\underline{\text { mvah@aqua.dtu.dk }}$

\begin{abstract}
The aquaculture industry needs new cost-effective solutions for removing effluent nitrogen to reduce their environmental impact. Recent studies have shown that laboratory and pilot-scale woodchip bioreactors can remove nitrate from aquaculture effluent. Encouraged by these results, several Danish fish farmers recently constructed commercial scale woodchip bioreactors prior to- or integrated into existing free water surface constructed wetlands without knowing the effects of design and upscaling on removal performance. The objective of the current study was to monitor initial performance (first 28 - 52 weeks of operation) of three such custom-designed denitrifying woodchip bioreactors installed in fullscale $\left(350,650\right.$, and $1250 \mathrm{~m}^{3}$ woodchips) for effluent treatment at three commercial recirculated rainbow trout (Oncorhynchus mykiss) farms.
\end{abstract}

All three woodchip bioreactors removed nitrogen (essentially nitrate-nitrogen) continuously from the start and at relatively stable rates $\left(5.3-8.5 \mathrm{~g} \mathrm{~N} / \mathrm{m}^{3} / \mathrm{d} ; 4.5-7.8 \mathrm{~g} \mathrm{NO}_{3}-\mathrm{N} / \mathrm{m}^{3} / \mathrm{d}\right)$ during the investigation period. Leaching of dissolved organic matter continued for up to half a year whereas there was no similar leaching of dissolved phosphorus. A net production of dissolved organic matter was observed under nitrate-limited conditions in one of the bioreactors characterized by a loading of 5.5 compared to 16.4$16.8 \mathrm{~g} \mathrm{NO}_{3}-\mathrm{N} / \mathrm{m}^{3} / \mathrm{d}$ at the other sites, and an empty bed contact time (EBCT) of $26 \mathrm{~h}$ compared to $15-16 \mathrm{~h}$ at the other sites. An increase in water level difference between inlet and outlet indicated that accumulation of particulate organic matter and associated bacterial growth may lead to head loss potentially reducing the long-term performance of the bioreactors. In conclusion, the study confirms that woodchip bioreactors can be applied at full-scale for removing $\mathrm{NO}_{3}-\mathrm{N}$ from fish farm effluent. Woodchip bioreactors should be designed to minimize head loss and the risk of clogging, and loading and retention time should ensure that denitrifiers do not become nitrate-limited. 


\section{Introduction}

Adoption of the European Water Framework Directive (WFD, 2000) by the EU member states in year 2000 motivated countries like Denmark, the Netherlands, and Germany to introduce stricter legislation on nutrient discharge from land-based fish farms (Bergheim and Brinker, 2003). In Denmark, this entailed that fish farmers are now primarily regulated by discharge control as opposed to previous feed quotas. Farmers are in principle allowed to produce as many fish as they wish as long as it is ensured that the discharge of total nitrogen (TN), total phosphorus (TP), total ammonia nitrogen (TAN), and organic matter (measured as biological oxygen demand; $\mathrm{BOD}_{5}$ ) are kept below given limits (Ministry of Environment and Food of Denmark, 2016). This has spurred a further growth and development of intensive land-based recirculating systems (RAS), mitigating environmental challenges by reducing water consumption and treating effluents (Dalsgaard et al., 2013).

According to Danish legislation (Ministry of Environment and Food of Denmark, 2016), farmers with an annual production above 25 tons must apply constructed wetlands for effluent treatment (Jokumsen and Svendsen, 2010). Constructed aquaculture wetlands with a long hydraulic retention time (HRT; $\geq 18 \mathrm{~h}$ ) have typical net removal capacities of TN, TP, and $\mathrm{COD}_{\text {total }}$ of 50,76 , and $93 \%$, respectively (Svendsen et al., 2008). The limited nitrogen removal is a challenge given that many farmers need to expand their production to ensure economic viability of their costly RAS systems, and there is an urgent need for practical and cost-effective solutions for reducing effluent nitrogen concentrations.

Recent laboratory and pilot-scale studies have suggested that technologically simple denitrifying woodchip bioreactors can be used for removing nitrate-nitrogen $\left(\mathrm{NO}_{3}-\mathrm{N}\right)$ from RAS effluent, and that HRT along with nitrate loading are important design parameters (Lepine et al., 2016; von Ahnen et al., 2016 a,b; Christianson and Schipper, 2016). Nitrate-nitrogen removal rates in these bioreactors typically follow zero order (substrate independent) removal kinetics (Robertson, 2010; von Ahnen et al., 2016a), and woodchip bioreactors with a long HRT (examining HRTs between $3.3-55 \mathrm{~h}$ ) may become nitrate limited, compromising $\mathrm{N}$ removal rates and leading to sulfate reduction and sulfide formation (Lepine et al., 2016; von Ahnen et al. 2016a). At similar N-loading, a longer HRT may consequently result in a higher removal efficiency (\%) while a shorter HRT may result in a higher removal rate $\left(\mathrm{g} \mathrm{NO}_{3}-\mathrm{N} / \mathrm{m}^{3} / \mathrm{d}\right)$ (Lepine et al., 2016; von Ahnen et al., 2016a).

In addition to HRT and N-loading, previous studies have shown that denitrification rates in woodchip bioreactors increase with temperature, and $Q_{10}$ values from 0.8 to 2.3 at temperatures ranging from 5 to 
$24{ }^{\circ} \mathrm{C}$ have been reported (Robertson et al., 2008; Robertson and Merkley, 2009; Cameron and Schipper, 2010; Warneke et al., 2011).

Christianson et al. (2016) addressed the risk of bioreactor clogging due to entrapment of organic solids transported with fish farm effluents. Clogging may potentially lead to accumulated bacterial growth, nutrient mineralization, altered hydraulics, and may shorten bioreactor life. To mitigate this risk, the authors advised that woodchip bioreactors are installed downstream of a mechanical filtration device.

von Ahnen et al. (2016b) investigated the start-up phase (first 147 days of operation) of a pilot-scale, woodchip bioreactor $\left(12.5 \mathrm{~m}^{3}\right)$ for the first time associated with a Danish commercial RAS. Applying a flow corresponding to an empty bed contact time (EBCT) of $5 \mathrm{~h}$, they found that dissolved TN was removed from day one at an average rate of $7.8 \pm 0.8 \mathrm{~g} \mathrm{TN} / \mathrm{m}^{3} / \mathrm{d}\left(8^{\circ} \mathrm{C}\right)$. Furthermore, an initial washout period of dissolved nutrients and dissolved organic compounds was observed lasting for approximately one week and causing a temporary increase in effluent dissolved organic matter concentrations, phosphorus, and TAN. The relatively low nitrogen removal rate compared to other $\mathrm{N}$ mitigation options for aquaculture (reviewed by van Rijn et al., 2016) implied that full-scale woodchip bioreactors for RAS should be in the size range of a couple of hundred cubic meters to handle a relatively large discharge flow from commercial RAS at the required retention time.

Adaption of new technology into the commercial sector often outpaces research and despite many unresolved design and operational issues such as: optimal inlet - outlet construction; which woodchip type to apply; optimal bioreactor depth; necessity for backwash; long-term performance; etc., three rainbow trout (Oncorhynchus mykiss) farmers in Denmark decided in year 2017 to install full-scale woodchip bioreactors and more farmers plan to do the same. The three bioreactors were customdesigned, taking site-specific conditions and requirements for effluent treatment into consideration. This resulted in somewhat different systems operated under similar environmental conditions, i.e., similar geographic location and water temperature range.

The objective of the current study was to monitor overall performance for up to a year of the three fullscale woodchip bioreactors operated under true field environmental conditions. It is the first study to monitor and assess commercial denitrification woodchip bioreactors under this context, and the purpose was to share performance results obtained and hands-on design and operational experiences with the aquaculture industry and scientific community addressing environmental concerns of $\mathrm{N}$ pollution from the aquaculture industry. 


\section{Materials and Methods}

\subsection{Study sites}

\subsubsection{Study site 1}

The first study site was a low recirculation intensity ( 75\%, calculated as: (recirculation flow - make-up water)/recirculation flow * 100) broodstock rainbow trout farm taking in $25 \mathrm{~L} / \mathrm{s}$ of groundwater as makeup water and feeding around $100 \mathrm{~kg}$ of feed per day (feed loading: $0.05 \mathrm{~kg} / \mathrm{m}^{3}$ make-up water). The main effluent was routed to a constructed free water surface wetland for polishing, while a side stream ( 15\%) was treated in a subsurface, horizontal flow woodchip bioreactor prior to entering the constructed wetland (figure 1).

The woodchip bioreactor, detailed in table 1, was installed in a previously applied $30 \mathrm{~m}$ long, $10 \mathrm{~m}$ wide and $1 \mathrm{~m}$ deep sedimentation basin. It was packed above water level with $350 \mathrm{~m}^{3}$ of a woodchip blend containing amongst others spruce (Picea sp.), poplar (Populus sp.) and beech (Fagus sp.). Packing above water level ensured that water flowed through the bioreactor rather than short-cutting above it. Water entered the woodchip bioreactor through three, $160 \mathrm{~mm}$ (outside diameter), polyvinyl chloride (PVC) drainage pipes placed at the bottom on one side of the bioreactor and stretching full length. Two similar outlet drainage pipes where placed on the opposite side forcing water to flow by gravity over the full width of the bioreactor. Water was directed via the outlet drainage pipes to an adjustable weir controlling the water level in the bioreactor. From the weir, water was led to the adjacent wetland before being discharged into the local stream.

The farmer periodically applied an unspecified "moderate dosage" (farmer's pers. com.) of hydrogen peroxide to the inlet drainage pipes to increase hydraulic conductivity at the bioreactor inlet side and reduce bioreactor head loss.

\subsubsection{Study site 2}

The farm at the second study site was a recirculating Model Trout Farm type III (MTF; Jokumsen and Svendsen, 2010) producing rainbow trout of approximately 600 - $1000 \mathrm{~g}$ for stocking in sea cages. It took in $30 \mathrm{~L} / \mathrm{s}$ of groundwater as make-up water and fed approximately $370 \mathrm{~kg}$ feed per day (feed loading: 0.14 $\mathrm{kg} / \mathrm{m}^{3}$ make-up water). 
Farm effluent entered a $2950 \mathrm{~m}^{2}$, free-water surface constructed wetland consisting of interconnected earthen ponds previously used for fish production. The first $2000 \mathrm{~m}^{2}$ of the wetland performed as a treatment zone before a side stream of $\sim 12 \mathrm{~L} / \mathrm{s}$ ( $\sim 40 \%)$ was split from the main flow and led through a vertical flow woodchip bioreactor integrated in an earthen pond (figure 1). Woodchip bioreactor effluent merged with the main wetland flow for polishing in the final $950 \mathrm{~m}^{2}$ part of the wetland before being discharged into the local stream.

The woodchip bioreactor, further specified in table 1, was $30 \mathrm{~m}$ long, $20 \mathrm{~m}$ wide and $1.1 \mathrm{~m}$ deep and filled with $650 \mathrm{~m}^{3}$ hardwood woodchips. Inlet water flooded the top of the woodchips via five PVC pipes sunk into the upstream earthen bank bounding the bioreactor towards the wetland side stream. This setup ensured an even downwards pressure and water flow across the bioreactor. Water left the bioreactor through ten $126 \mathrm{~mm}$ (outside diameter) PVC drainage pipes placed over the full length at the bottom of the bioreactor and penetrating the earthen bank at the bioreactor outlet side. Each drainage pipe was connected to an adjustable elbow pipe at the outlet side, enabling the farmer to regulate the amount of water discharged from each drainage pipe. In addition, each drainage pipe was mounted with three, regularly situated vertical standpipes reaching some $50 \mathrm{~cm}$ above water level enabling the farmer to backwash the drainpipes and allegedly reduce head loss across the bioreactor.

\subsubsection{Study site 3}

The recirculated MTF type III at the third study site produced 600 tons of portion sized rainbow trout per year, taking in groundwater at $30 \mathrm{~L} / \mathrm{s}$ as make-up water (feed loading: 0.57 kg/m $\mathrm{m}^{3}$ make-up water). Farm effluent and the overflow from a sludge basin entered a $7500 \mathrm{~m}^{2}$ meandering constructed wetland including a woodchip bioreactor integrated approximately half way through the wetland and followed by a final wetland section for effluent polishing (figure 1).

The woodchip bioreactor, further specified in table 1, was approximately $60 \mathrm{~m}$ long, $20 \mathrm{~m}$ wide and $1.2 \mathrm{~m}$ deep and contained $1250 \mathrm{~m}^{3}$ hardwood woodchips. It was constructed as a vertical flow bioreactor similar to the woodchip bioreactor at site 2, with twelve $126 \mathrm{~mm}$ (outside diameter) regularly distributed PVC drainage pipes at the bottom reaching full length. A stainless steel grid at the inlet side supported by wooden poles kept the woodchips in place, while a wooden wall held them back at the outlet side. Water entered the bioreactor through the grid on the inlet side, spread out over the entire woodchip packing, flowed downwards through the woodchips, and left the bioreactor via the bottom drainage pipes. The drainage pipes penetrated the wooden wall at the outlet side and were mounted with adjustable elbow pipes for water flow regulation. Similar to study site 2, vertical stand pipes were connected to the 
drainpipes for potential periodical backwashing and to prevent accumulation of gas in the pipes making them float and interfere with flow dynamics as initially observed by the farmer.

\subsection{Water sampling and analyses}

Grab samples of $5 \mathrm{~L}$ were taken from the inlet and outlet of the woodchip bioreactors at the same time of day $( \pm 1 \mathrm{~h}$ ) every third week. During water sampling, point measurements of oxygen, $\mathrm{pH}$, and temperature were obtained using a portable meter (Hach Lange HQ40 multimeters, Düsseldorf, Germany). Sampling at site 1 began $24 \mathrm{~h}$ after bioreactor startup, while sampling at sites 2 and 3 was initiated six and seven weeks, respectively, after startup. Study sites 1 and 3 were sampled over a period of one full year (52 weeks) while site 2 was sampled for 28 weeks.

Per ISO methods samples were kept on ice/refrigerated (at $3^{\circ} \mathrm{C}$ ) until analysis. Subsamples (1000 $\mathrm{mL}$ ) were filtered through $0.45 \mu \mathrm{m}$ mixed cellulose ester filters (Whatman, GE Healthcare, UK) prior to analyses

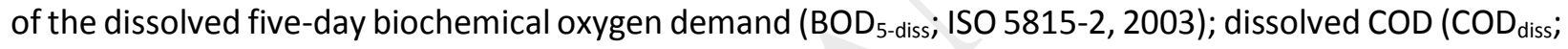
ISO 15705, 2002; Spectroquant ${ }^{\circledR}$ test kits, Merck Millipore, Darmstadt, Germany); and orthophosphate (ortho-P). Other subsamples were filtered through $0.2 \mu \mathrm{m}$ syringe filters (Filtropur S $0.2 \mu \mathrm{m}$, Sarstedt,

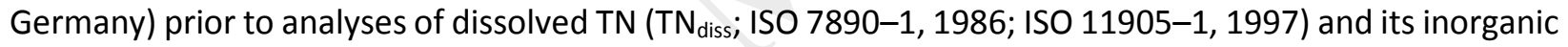
$\mathrm{N}$-forms including TAN (DS224, 1975); nitrite-N (NO2-N; DS 223, 1991); and nitrate-N ( $\mathrm{NO}_{3}-\mathrm{N}$; ISO 7890-1, 1986). Finally, unfiltered sub-samples were analysed for TN (ISO 7890-1, 1986; ISO 11905-1, 1997); total

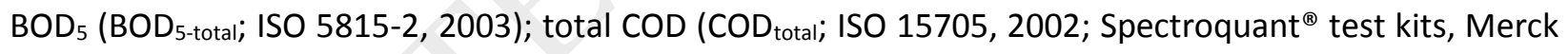
Millipore, Darmstadt, Germany); and total phosphorus (TP; ISO 6878, 2004). Analyses of $\mathrm{BOD}_{5}$ were initiated on the day of sampling while all other analyses were performed within the first few days following collection. Unfiltered and filtered subsamples for $\mathrm{COD}_{\text {total }}, \mathrm{COD}_{\text {diss, }}$ ortho-P, and TP analyses were preserved until analysis by adding $1 \%$ sulfuric acid $\left(\mathrm{H}_{2} \mathrm{SO}_{4} ; 21.4 \%\right.$, Merck KGaA, Darmstadt, Germany). The first $\mathrm{BOD}_{5}$ measurements were carried out 8 weeks into the monitoring program.

\subsection{Calculation of removal rates, total woodchip porosity and correlation analyses}

Total woodchip porosity (\%) was determined by filling air-dried woodchips into a $1 \mathrm{~L}$ bottle, adding water to the $1 \mathrm{~L}$ mark, closing the bottle with a lid, refilling after $24 \mathrm{~h}$ to account for any absorbed water, and calculating total porosity from the total water volume applied (Christianson et al., 2010). 
Volumetric removal rates $\left(\mathrm{g} / \mathrm{m}^{3} / \mathrm{d}\right)$ were calculated based on concentration differences between inlet and outlet grab samples divided by the EBCT. Empty bed contact time was calculated as the volume of submerged woodchips divided by flow rate, disregarding woodchip media porosity and taking into account that only $250 \mathrm{~m}^{3}$ of the total $350 \mathrm{~m}^{3}$ woodchips at site 1 were submerged.

Flow rates (L/s) were measured on each sampling event (inflow at site 3 and outflow at site 1 and 2 ) to account for any variations throughout the sampling period. They were derived by measuring width and height of an overflow and applying "Torricelli's Law" at sites 1 and 3, or as discharge from the bioreactor outlet pipes at site 2 using a bucket and a stop watch.

None of the bioreactors were lined as they were established in a previous sedimentation basin (site 1) or in a previous part of a constructed wetland (site 2 and 3), and it was therefore assumed that there was no significant leakage or infiltration affecting overall water balances.

Spearman correlation analyses were carried out in SigmaPlot version 13.0 (Systat Software Inc., CA, USA). Results are throughout presented as means \pm SD.

\section{Results}

Woodchip bioreactor specifications are summarized in table 1, while average in- and outlet nutrient and organic matter concentrations as well as average oxygen, $\mathrm{pH}$, and temperature measures are summarized in table 2.

\subsection{Nitrogen removal}

All three study sites showed continuous and relatively stable removal of TN with removal rates between 5.3 and $8.5 \mathrm{~g} \mathrm{TN} / \mathrm{m}^{3} / \mathrm{d}$ (table 2 and figure 2a) being lowest at site 1 and highest at site 2 . Total $\mathrm{N}$ removal rates were generally closely matched by those of $\mathrm{TN}_{\text {diss }}$ and $\mathrm{NO}_{3}-\mathrm{N}$ with the latter ranging between 4.5 and $7.8 \mathrm{~g} \mathrm{NO}_{3}-\mathrm{N} / \mathrm{m}^{3} / \mathrm{d}$ (table 2 and figure $2 \mathrm{~b}$ ). Nitrate-nitrogen constituted 84,84 , and $92 \%$ of $\mathrm{TN}$ removal at site 1,2 , and 3 , respectively.

Comparatively lower removal rates of TAN, ranging between 0.0 and $0.7 \mathrm{~g} \mathrm{TAN} / \mathrm{m}^{3} / \mathrm{d}$ and with periodic net production of TAN, were measured at all sites (table 2 and figure $2 \mathrm{~g}$ ). Similarly, low removal rates of $\mathrm{NO}_{2}-\mathrm{N}$ were measured at site 1 and $3\left(0.1\right.$ and $\left.0.4 \mathrm{~g} \mathrm{NO}_{2}-\mathrm{N} / \mathrm{m}^{3} / \mathrm{d}\right)$, while there was a net production of $\mathrm{NO}_{2}-\mathrm{N}$ at site $2\left(0.3 \mathrm{~g} \mathrm{NO}_{2}-\mathrm{N} / \mathrm{m}^{3} / \mathrm{d}\right.$ ) (table 2 and figure $2 \mathrm{c}$ ).

No significant correlations were found between temperature and removal rates of $\mathrm{NO}_{3}-\mathrm{N}$ or TN. 


\subsection{Organic matter removal}

There was a net production/leakage of dissolved organic matter during the first half year of operation at all sites declining steadily over time. Subsequent to the first 26 weeks of operation, i.e., when leaching appeared to have stopped and bioreactors stabilized, $\mathrm{BOD}_{5 \text {-total }}$ was removed at average rates of $2.0 \pm 0.3$ and $0.2 \pm 1.5 \mathrm{~g} \mathrm{BOD}_{5 \text {-total }} / \mathrm{m}^{3} / \mathrm{d}$ (figure $2 \mathrm{~d}$ ) at sites 2 and 3, respectively, and $\mathrm{COD}_{\text {total }}$ at average rates of 2.2 \pm 0.3 and $0.4 \pm 5.2 \mathrm{~g} \mathrm{COD}_{\text {total }} / \mathrm{m}^{3} / \mathrm{d}$ (figure $2 \mathrm{e}$ ). In terms of dissolved organic matter in this period, $\mathrm{BOD}_{5 \text {-diss }}$ was removed at an average rate of $1.4 \pm 0.6$ and $0.3 \pm 3.9 \mathrm{~g} \mathrm{BOD}_{5-\text { diss }} / \mathrm{m}^{3} / \mathrm{d}$ at sites 2 and 3 , respectively, with corresponding $\mathrm{COD}_{\text {diss }}$ removal rates of $2.2 \pm 2.2$ and $4.3 \pm 7.2 \mathrm{~g} \mathrm{COD}$ diss $/ \mathrm{m}^{3} / \mathrm{d}(\mathrm{n}=3$ and 12 , respectively, for all organic components).

In contrast, there was a constant net production of organic matter at site 1 throughout the whole measuring period, with net production rates of $\mathrm{BOD}_{5 \text { - total }}$ and $\mathrm{COD}_{\text {total }}$ subsequent to the first 26 weeks of operation of $5.2 \pm 3.9$ and $8.9 \pm 7.9 \mathrm{~g} / \mathrm{m}^{3} / \mathrm{d}(\mathrm{n}=9$; figure $2 \mathrm{~d}$ and $2 \mathrm{e})$. Dissolved organic matter production rates succeeding the first 26 weeks amounted to $4.7 \pm 3.6 \mathrm{~g} \mathrm{BOD}_{5-\text { diss }} / \mathrm{m}^{3} / \mathrm{d}$ and $7.5 \pm 6.8 \mathrm{~g} \mathrm{COD}$ diss $/ \mathrm{m}^{3} / \mathrm{d}$ (n=9; figure $2 f)$.

\subsection{Phosphorus removal}

A small production/leaching or removal of TP was observed at all study sites with average removal rates between -0.2 and $0.1 \mathrm{~g} \mathrm{TP} / \mathrm{m}^{3} / \mathrm{d}$ (table 2 and figure $2 \mathrm{f}$ ). Similarly, ortho-P removal rates ranged between -0.1 and $0.1 \mathrm{~g} \mathrm{PO}_{4}-\mathrm{P} / \mathrm{m}^{3} / \mathrm{d}$ (table 2).

No significant correlations were found between temperature and removal rates of TP or $\mathrm{PO}_{4}-\mathrm{P}$.

\subsection{Temperature, oxygen, and $\mathrm{pH}$}

Inlet bioreactor temperatures at the three study sites were similar on each specific sampling day averaging $9.9-10.4{ }^{\circ} \mathrm{C}$ and with seasonal fluctuations between 4.5 and $15.6{ }^{\circ} \mathrm{C}$ (table 2). Oxygen inlet values decreased from 9.0 at site 1 to $3.2-1.9 \mathrm{mg} \mathrm{O} / \mathrm{L}$ at site 2 and 3, respectively, while corresponding average outlet values were all below $1 \mathrm{mg} / \mathrm{L}$ (table 2). There was generally a decline in $\mathrm{pH}$ from inlet to outlet at all sites, declining from 7.2 - 7.5 to 7.0 - 7.3 (table 2). 


\section{Discussion}

\subsection{Nitrate-N removal rates}

The average $\mathrm{NO}_{3}-\mathrm{N}$ removal rates obtained during the first 28 - 52 weeks of woodchip bioreactor operations (4.5 - $7.8 \mathrm{~g} \mathrm{NO}_{3}-\mathrm{N} / \mathrm{m}^{3} / \mathrm{d}$ ) fit well within the lower range of $\mathrm{NO}_{3}-\mathrm{N}$ removal rates documented for full-scale woodchip bioreactors applied for drainage water treatment (2 - $22 \mathrm{~g} \mathrm{~N} / \mathrm{m}^{3} / \mathrm{d}$; Schipper et al., 2010b; Christianson et al., 2012). Nitrate removal rates in denitrifying woodchip bioreactors applied for treating agricultural drainage water have been shown to decline after the first year of operation and then stabilize (Addy et al., 2016). Long-term (> 1 year) removal performance cannot be derived from the current study, however, there were no indications of a decline in performance.

The relatively low removal rates and lack of a temperature relationship may in part be due to the low water temperatures measured during the year, averaging $\sim 10{ }^{\circ} \mathrm{C}$ and including transitory minimums and maximums of 4.5 and $15.6^{\circ} \mathrm{C}$. All three farms used groundwater $\left(6-8^{\circ} \mathrm{C}\right)$ as make-up water and this, combined with other uncontrollable environmental parameters, presumably reduced the impact of seasonal fluctuations on removal performance. Hover et al. (2016) found similar $\mathrm{NO}_{3}-\mathrm{N}$ removal rates (6.1 $\pm 0.4 \mathrm{~g} \mathrm{NO}_{3}-\mathrm{N} / \mathrm{m}^{3} / \mathrm{d}$ ) in laboratory woodchip bioreactors operated at influent $\mathrm{NO}_{3}-\mathrm{N}$ concentration of 10 $\mathrm{mg} / \mathrm{L}$ and a temperature of $10^{\circ} \mathrm{C}$. Furthermore, our results are largely consistent with those of Robertson and Merkley (2009) showing that denitrification in woodchip bioreactors may proceed at temperatures as low as $2-4^{\circ} \mathrm{C}$.

The lowest average $\mathrm{NO}_{3}-\mathrm{N}$ removal rate was measured at study site 1 characterized by an EBCT of $25.7 \mathrm{~h}$ compared to $14.8-15.9 \mathrm{~h}$ at the other two sites, and a corresponding $\mathrm{NO}_{3}-\mathrm{N}$ loading of 5.5 compared to 16.4 - $16.8 \mathrm{~g} \mathrm{NO}_{3}-\mathrm{N} / \mathrm{m}^{3} / \mathrm{d}$. As expected, the longer EBCT and lower $\mathrm{N}$-loading resulted in a high $\mathrm{NO}_{3}-\mathrm{N}$ removal efficiency (Lepine et al., 2016), averaging $80 \%$ compared to 29 - $48 \%$ at the other sites. Furthermore, outlet $\mathrm{NO}_{3}-\mathrm{N}$ concentrations were very low at site 1 compared to site 2 and 3 (1.0 vs. 4.9 7.5; table 2), indicating that the bioreactor was nitrate limited (Robertson, 2010; von Ahnen et al., 2016a). Consistently, there was a constant production/leakage of organic matter at this site and the outlet water was characterized by a sulfurous smell (author's pers. obs.). Hydrogen sulfide $\left(\mathrm{H}_{2} \mathrm{~S}\right)$ concentrations were not measured, but a high abundance of sulphide oxidizing epsilonproteobacterial Campylobacterales (Suurnäkki et al., unpublished data) was identified in the biofilm at the woodchip bioreactor outlet using next generation sequencing (NGS), indicating that reduced sulfur compounds were present. As mentioned earlier, undesirable processes like sulfate reduction (Blowes et al., 1994; Robertson and Merkley, 2009; van Driel et al., 2006) may occur under nitrate-limited conditions accompanied by a net production of 
organic matter. Elevated organic matter outlet concentrations were thus measured by Christianson et al. (2017) who, in a laboratory-scale woodchip column study, found a correlation between the percentage of COD released and sulfate reduced when the $\mathrm{NO}_{3}$ removal efficiency was above $90 \%$. The shorter EBCT and higher outlet $\mathrm{NO}_{3}-\mathrm{N}$ concentrations at site 2 and 3 ensured that these systems did not become $\mathrm{NO}_{3}$ $\mathrm{N}$ limited, reducing further the risk of sulfate reduction and a concomitant release of organic matter.

Although high removal efficiencies and minimum effluent $\mathrm{NO}_{3}-\mathrm{N}$ concentrations might seem desirable from an environmental point of view, there is no incentive for farmers to aim this low and risk that bioreactors become $\mathrm{NO}_{3}-\mathrm{N}$ limited. Denmark is an intensively cultivated country and zero $\mathrm{NO}_{3}-\mathrm{N}$ concentrations are rarely measured in natural water courses (Wiberg-Larsen et al., 2013). Farmers are obviously not required to remove $\mathrm{NO}_{3}-\mathrm{N}$ below background levels. Those that produce more than 25 tons per year have specified limits as to how much net BOD $_{5 \text {-total, }}$ TP and TN they may discharge per day and year, and they are typically allowed to add a limited amount on top of farm inlet concentrations (Ministry of Environment and Food of Denmark, 2016). To reduce effluent treatment costs and optimize investment costs, farmers will most likely aim at optimizing volumetric removal rates rather than removal efficiency. To illustrate; only a fraction of total effluent was treated in the woodchip bioreactor at site 1 (table 1), and more $\mathrm{N}$ could have been removed each day if more of the total effluent had been led through the bioreactor although this would have lowered the removal efficiency of the bioreactor. Hence, for the most optimal use of the bioreactor, retention time should generally be such that outlet concentrations are above $3 \mathrm{mg} \mathrm{NO} 3-\mathrm{N} / \mathrm{L}$ to avoid any nitrate limitation (Robertson, 2010; von Ahnen et al., 2016a).

\subsection{Organic matter and nutrient leaching}

It is well documented that there is a release of organic matter during woodchip bioreactor start-up (Gibert et al., 2008; Cameron and Schipper, 2010; Healy et al., 2012; von Ahnen et al., 2016b). Organic matter leaching was not measured during the first 6 - 7 weeks of bioreactor operation at study site 2 and 3. Assuming, however, that there had been a release as high- or higher than that measured in week $7-8$, there had been a net production of organic matter lasting for about half a year at these sites. In comparison, a continuous release of organic matter was observed at site 1 . The observations at sites 2 and 3 are consistent with several woodchip bioreactor field studies within agricultural water treatment where an initial dissolved organic carbon peak typically dissipates after 3 - 6 months (e.g., Robertson et al., 2005; Schipper et al., 2010a; Healy et al., 2012). Duration and magnitude of the initial leaching period depends on bioreactor retention time (Schipper et al., 2010b). An initial organic matter washout period of only 3 weeks was thus observed in a pilot-scale woodchip bioreactor situated at a commercial RAS farm 
(von Ahnen et al., 2016b). The pilot-scale bioreactor was operated at a relatively short EBCT of $5 \mathrm{~h}$ compared to 16 and $15 \mathrm{~h}$ at sites 2 and 3 in the current study, and received a similar nutrient loading. Leaching may continue if retention time (relative to nitrate loading conditions) becomes too long as observed at site 1 , where the constant release of organic matter probably was due to bacterial activity rather than physical processes/diffusive leaching.

Different carbon sources may also affect leaching with typically faster leaching from more labile carbon sources (Gibert et al., 2008). Willow (mix of Salix viminalis $\times$ Salix schwerinii) was used in the pilot-scale bioreactor discussed above while hardwood woodchips were applied in the three commercial-scale bioreactors, and this may have added to prolong the leaching period. The practical nature of the present study did not allow for an evaluation of the most optimal wood species to apply for treating aquaculture effluents. Further studies are therefore needed to evaluate the performance and overall economy of using different wood species. Here, it should also be taken into account that many farmers are appealed by the possibility of growing trees themselves saving costs and providing even higher sustainability to the technology.

As also observed in the pilot-scale study by von Ahnen et al. (2016b), organic matter leaching was accompanied by a decline in $\mathrm{pH}$ from inlet to outlet that diminished over time. Low outlet $\mathrm{pH}$ values are commonly observed just after woodchip bioreactor startup increasing slowly during the following days/weeks (Lepine et al. 2016), and is probably due to an initial washout of dissolved organic acids stored in woodchips. A low initial pH may additionally be caused by a release of $\mathrm{CO}_{2}$ deriving from previous aerobic heterotrophic respiration of organic matter. Finally, it is highly likely that some extent of (sulfurbased) autotrophic denitrification takes place within woodchip bioreactors (von Ahnen et al., 2016a, 2018), contributing to lowering outlet $\mathrm{pH}$.

As opposed to organic matter, no extensive leaching of dissolved phosphorus from the three woodchip bioreactors was observed neither during the first half year of operation nor during ongoing operation. When observed, leaching of phosphorus does typically not last as long as leaching of organic matter, and the most rapid release seems to happen during the first $24 \mathrm{~h}$ (Sharrer et al., 2016; von Ahnen et al., 2016b). On average, there was a miniscule net removal of phosphorus at sites 2 and 3 , and the capability of these wood-based bioreactors to remove smaller amounts of phosphates is consistent with previous woodchip bioreactor studies (e.g., Schipper et al., 2010a; Warneke et al., 2011; Sharrer et al., 2016). In contrast, a net production of dissolved phosphorus at site 1 was probably caused by the longer retention time and nitrate-limited conditions triggering other types of respiratory processes in the bioreactor. 
Leakage of dissolved organic matter and other non-characterized components from woodchips may have hazardous effects on receiving water bodies (Tao et al., 2005), and this should be taken into account when planning an aquaculture woodchip bioreactor. In the current study, the bioreactors at site 2 and 3 were integrated into existing constructed wetlands including an upstream and downstream wetland section. Upstream sections supposedly allowed particulate organic matter to settle prior to the woodchip bioreactors reducing the risk of clogging (Christianson et al. 2016; Dalsgaard et al., 2018), while downstream sections served to dilute and remove any organic matter and other components before water was finally discharged to the local stream.

\subsection{Clogging and head loss}

The woodchip bioreactors at site 2 and 3 were designed as open pits as opposed to, e.g., covered, horizontal woodchip bioreactors typically applied for treating agricultural drainage water (Schipper et al., 2010, Christiansen et al., 2012). This was done to ensure an even distribution and downwards pressure of water across the bioreactors. After a few weeks of operation large parts of the woodchip media, however, began to float due to the development and release of (nitrogen) gas following denitrification and gas bubbles being trapped on woodchip surfaces lifting them upwards. The bioreactors thus seemed to "boil" (author's pers. obs.), and a permanent layer of floating woodchips approximately $50 \mathrm{~cm}$ in thickness developed over time. This may have favored an uneven distribution and channeling of water but as the woodchips were still submerged the removal rate calculations were assumed to still apply and the overall removal seemed unaffected. The formation of bubbles did, however, make it necessary to moor the drainage pipes to the ground with sand sacks as they would otherwise also start to float. A similar issue with floating woodchips was not observed in the horizontal bioreactor at site 1 where the weight of emergent woodchips kept the submerged woodchips in place.

An increase in head loss across the woodchip bioreactors was observed during the monitoring period. This also applied to the bioreactors at study sites 2 and 3 despite upstream wetland sections where particulate organic matter supposedly would settle (Dalsgaard et al. 2018). In addition to particulate organic matter accumulation, which was visible if stepping into the bioreactor at site 3 at the inlet side (author's pers. obs.), bioreactor clogging may also have been caused by heterotrophic bacteria growing in voids between woodchips and as biofilm on drainage pipes.

The increase in head loss during the first weeks of operation at sites 1 and 2 caused a reduction in flow rates through the bioreactors as more water bypassed them as a consequence. At site 3 , an increase in water level differences between bioreactor inlet and outlet was observed reaching $30 \mathrm{~cm}$ after one year 
despite periodically backwashing of the drainage pipes through the vertical standpipes. Hence, although all three farmers reported a visible reduction in head loss by a few centimeters after applying their individual backwashing methods some degree of clogging seems unavoidable and might affect bioreactor long-term performance. To counteract this, it could be advantageous to design the bioreactors in a way that the most upstream part could easily be removed and replaced if/when necessary. In addition, vertical bioreactors typically provide a much larger inflow area relative to volume compared to horizontal bioreactors, reducing the water velocity and providing a larger area for particles to settle, both factors significantly reducing the risk of clogging.

\section{Conclusions}

Full-scale woodchip bioreactors may be implemented for effluent $\mathrm{NO}_{3}-\mathrm{N}$ removal at freshwater recirculating fish farms. Woodchip bioreactors seem to achieve relatively stable, year-round $\mathrm{NO}_{3}-\mathrm{N}$ removal rates (at least within the measured 4.5 to $15.6{ }^{\circ} \mathrm{C}$ temperature span examined in the current study) with relatively little technological- and operational effort. Commercial woodchip bioreactors must, however, be carefully designed in order to reduce the risk of clogging and concomitant head loss, drainage pipes in vertical bioreactors should be moored to the ground to keep them from lifting, and options for periodical backwash of sections where particle accumulation might be pronounced should be established. Retention time should be short enough to ensure that denitrifiers do not become $\mathrm{NO}_{3}-\mathrm{N}$ limited, and situating the bioreactor should take an initial washout period of organic matter and other potentially harmful components into account. Given these precautions and the fact that woodchip bioreactors are relatively easy to install, easy to operate, and that woodchips eventually may be obtained from trees grown on site makes woodchip bioreactors an appealing, cost-effective, "new" end-of-pipe treatment technology in aquaculture for reducing nitrogen discharge. Effects of salinity and potential application of woodchip bioreactors for treating marine RAS effluent warrants further studies, as does the effect of different tree species on nutrient leakage and removal performance.

\section{Acknowledgements}

The study was partly funded by the Ministry of Environment and Food of Denmark and by the European Maritime and Fisheries Fund (EMFF) as part of project “End-of-Pipe rensning på dambrug" (J.no. 33111-I16-046). We thank the fish farmers for allowing us access to their facilities and to the laboratory 
technicians Ulla Sproegel, Brian Møller, and Dorthe Frandsen (DTU Aqua) for invaluable technical laboratory and field assistance. 


\section{References}

Addy, K., Gold, J.A., Christianson, L.E., David, M.B., Schipper, L.A., Ratigan, N.A., 2016. Denitrifying bioreactors for nitrate removal: A meta-analysis. Journal of Environmental Quality 45 (3), 873-881.

Bergheim, A., Brinker, A., 2003. Effluent treatment for flow through systems and European Environmental Regulations. Aquacultural Engineering 27, 61-77.

Blowes, D.W., Robertson, W.D., Ptacek, C.J., Merkley, C., 1994. Removal of agricultural nitrate from tiledrainage effluent water using in-line bioreactors. Journal of Contaminant Hydrology 15, 207-221.

Cameron, S.G., Schipper, L.A., 2010. Nitrate removal and hydraulic performance of organic carbon for use in denitrification beds. Ecological Engineering 36, 1588-1595.

Christianson, L.E., Castelló, A., Christianson, R., Herlmers, M., Bhandari, A., 2010. Technical note: hydraulic property determination of denitrifying bioreactor fill media. Applied Engineering in Agriculture 26 (5), 849-854.

Christianson, L.E., Bhandari, A., Helmers, M.J., 2012. A practice-oriented review of woodchip bioreactors for subsurface agricultural drainage.

Christianson, L.E., Schipper, L.A., 2016. Moving Denitrifying Bioreactors beyond Proof of Concept: Introduction to the Special Section. Journal of Environmental Quality 45, 757-761.

Christianson, L.E., Lepine, C., Sharrer, K.L., Summerfelt, S., 2016. Denitrifying bioreactor clogging potential during wastewater treatment. Water Research 105, 147-156.

Christianson, L.E., Lepine, C., Sibrell, P.L., Penn, C., Summerfelt, S.T., 2017. Denitrifying woodchip bioreactor and phosphorous filter pairing to minimize pollution swapping. Water Research 121, 129-139.

Dalsgaard, J., Lund, I., Thorarinsdottir, R., Drengstig, A., Arvonen, K., Pedersen, P.B., 2013. Farming different species in RAS in Nordic countries: Current status and future perspectives. Aquacultural Engineering 53, 2- 13.

Dalsgaard, J., von Ahnen, M., Naas, C., Pedersen, P.B., 2018. Nutrient removal in a constructed wetland treating aquaculture effluent at short hydraulic retention time. Aquaculture Environment Interactions, 10, 329-343.

DS 223, 1991. Water analysis-Determination of the sum of nitrite- and nitrate-nitrogen. Danish Standards Foundation, Charlottenlund, Denmark.

DS 224, 1975. Water analysis-Determination of ammonia-nitrogen. Danish Standards Foundation, Charlottenlund, Denmark.

Gibert, O., Pomierny, S., Rowe, I., Kalin, R.M., 2008. Selection of organic substrates as potential materials for use in a denitrification permeable reactive barrier (PRB). Bioresource Technology 99, 7587-7596.

Healy, M.G., Ibrahim, T.G., Lanigan, G.J., Serrenho, A.J., Denton, O., 2012. Nitrate removal rate, efficiency and pollution swapping potential of different organic carbon media in laboratory denitrification bioreactors. Ecological Engineering 40, 198-209. 
Hover, N.L., Bhandari, A., Soupir, M.L., Moorman, T.B., 2016. Woodchip denitrification bioreactors: impact of temperature and hydraulic retention time on nitrate removal. Journal of Environmental Quality 45, 803-812.

ISO 15705, 2002. Water quality-Determination of the chemical oxygen demand index (ST-COD)-Smallscale sealed-tube method. International Organization for Standardization, Geneva, Switzerland.

ISO 5815-2, 2003. Water quality-Determination of biochemical oxygen demand after $\mathrm{n}$ days (BODn)Part 2: Method for undiluted samples, ISO 5815-2:2003, modified. International Organization for Standardization, Geneva, Switzerland.

ISO 6878, 2004. Water quality-Determination of phosphorus-ammonium molybdate spectrometric method. International Organization for Standardization, Geneva, Switzerland. ISO 7890-1, 1986. Water quality-Determination of nitrate. Part 1: 2.6-Dimethylphenol spectrometric method. International Organization for Standardization, Geneva, Switzerland.

ISO 11905-1, 1997. Water quality-Determination of nitrogen. Part 1: Method using oxidative digestion with peroxodisulfate. International Organization for Standardization, Geneva, Switzerland.

Jokumsen, A., Svendsen, L.M., 2010. Farming of freshwater rainbow trout in Denmark. DTU Aqua Rep 2192010, Technical University of Denmark.

Lepine, C., Christianson, L., Sharrer, K., Summerfelt, S., 2016. Optimizing hydraulic retention times in denitrifying woodchip bioreactors treating recirculating aquaculture system wastewater. Journal of Environmental Quality 45 (3), 813-821.

Ministry of Environment and Food of Denmark, 2016. Bekendtgørelse om miljøgodkendelse og samtidig sagsbehandling af ferskvandsdambrug (in Danish). Lovtidende A, BEK nr 1567 af 07/12/2016. Ministry of Environment and Food of Denmark.

Robertson, W.D., 2010. Nitrate removal rates in woodchip media of varying age. Ecological Engineering $36,1581-1587$

Robertson, W.D., Yeung, N., van Direl, P.W., Lombardo, P.S., 2005. High-permeability layers for remediation of ground water; go wide, not deep. Ground Water 43, 574-581.

Robertson, W.D., Vogan, J.L., Lombardo, P.S., 2008. Nitrate removal rates in a15-year old permeable reactive barrier treating septic system nitrate. Groundwater Monitoring and Remediation. 28, 65-72.

Sharrer, K.L., Christianson, L.E., Lepine, C., Summerfelt, S.T., 2016. Modeling and mitigation of denitrification 'woodchip' bioreactor phosphorous releases during treatment of aquaculture wastewater. Ecological Engineering 93, 135-143.

Schipper, L.A., Cameron, S., Warneke, S., 2010a. Nitrate removal from three different effluents using largescale denitrification. Ecological Engineering 36, 1552-1557.

Schipper, L.A., Robertson, W.D., Gold, A.J., Jaynes, D.B., Cameron, S.C., 2010b. Denitrifying bioreactorsAn approach for reducing nitrate loads to receiving waters. Ecological Engineering 36, 1532-1543.

Svendsen, L.M., Sortkjær, O., Ovesen, N.B., Skriver, J., Larsen, S.E., Bouttrup, S., Pedersen, P.B., Rasmussen, R.S., Dalsgaard, A.J.T., Suhr, K., 2008. Modeldambrug under forsøgsordningen. Faglig 
slutrapport for måle- og dokumentationsprojekt for modeldambrug (in Danish). DTU Aqua Res Rep 19308, Technical University of Denmark.

Tao, W., Hall, K.J., Masbough, A., Frankowski, K., Duff, S.J.B., 2005. Characterization of leachate from woodwaste pile. Water Quality Research Journal of Canada 40 (4), 476-483.

Van Driel, P.W., Robertson, W.D., Merkley, L.C., 2006. Denitrification of agricultural drainage using woodbased reactors. Transactions of the ASABE 49, 565-573.

Van Rijn, J., Tal, Y., Schreier, H.J., 2006. Denitrification in recirculating systems: theory and applications. Aquacultural Engineering 34, 364-376.

Von Ahnen, M., Pedersen, P.B., Hoffmann, C.C., Dalsgaard, J., 2016a. Optimizing nitrate removal in woodchip beds treating aquaculture effluents. Aquaculture458, 47-54.

Von Ahnen, M., Pedersen, P.B., Dalsgaard, J., 2016b. Start-up performance of a woodchip bioreactor operated end-of-pipe at a commercial fish farm - a case study. Aquacultural Engineering 74, 96-104.

Von Ahnen, M., Pedersen, P.B., Dalsgaard, J., 2018. Nitrate removal from aquaculture effluents using woodchip bioreactors improved by adding sulfur granules and crushed seashells. Water Science \& Technology 77(9-10), 2301-2310.

Warneke, S., Schipper, L.A., Bruesewitz, D.A., McDonald, I., Cameron, S., 2011. Rates, controls and potential adverse effects of nitrate removal in a denitrification bed. Ecological Engineering 37, 511-522.

WFD, 2000. Directive 2000/60/EC of the European Parliament and of the Council of 23 October 2000, establishing a framework for community action in the field of water policy. Official Journal of the European Communities, L 327/1 - L 327/72.

Wiberg-Larsen, P., Windolf, J., Bøgestrand, J., Baattrup-Pedersen, A., Kristensen, E.A., Larsen, S.E., Thodsen, H., Ovesen, N.B., Bjerring, R., Kronvang, B., Blicher-Mathiesen, G., Kjeldgaard, A. 2013. Vandløb 2012, NOVANA (in Danish). Aarhus Universitet, DCE - Nationalt Center for Miljø og Energi, Denmark. Videnskabelig rapport fra DCE - Nationalt Center for Miljø og Energi nr. 75. 
Figure captions

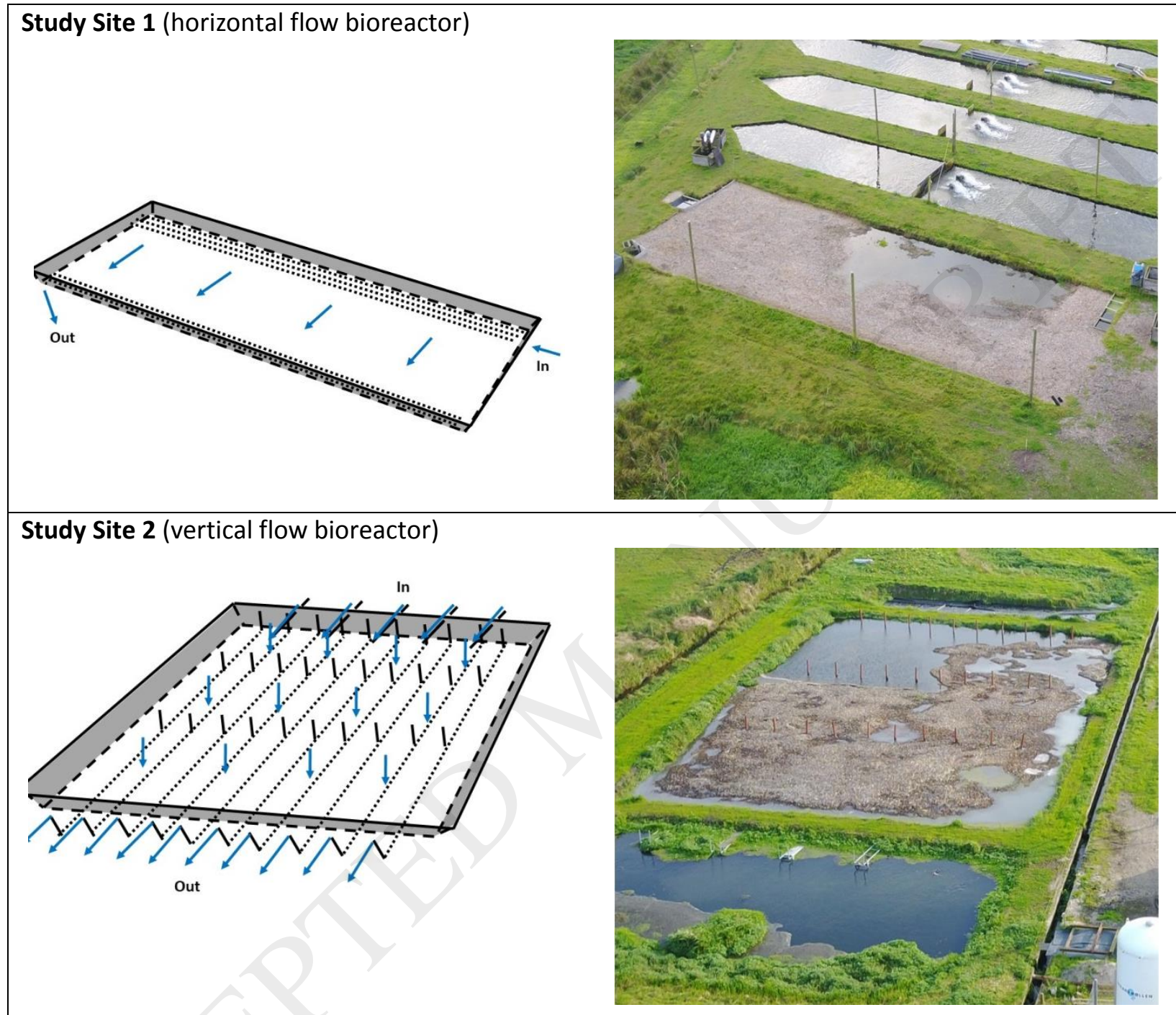




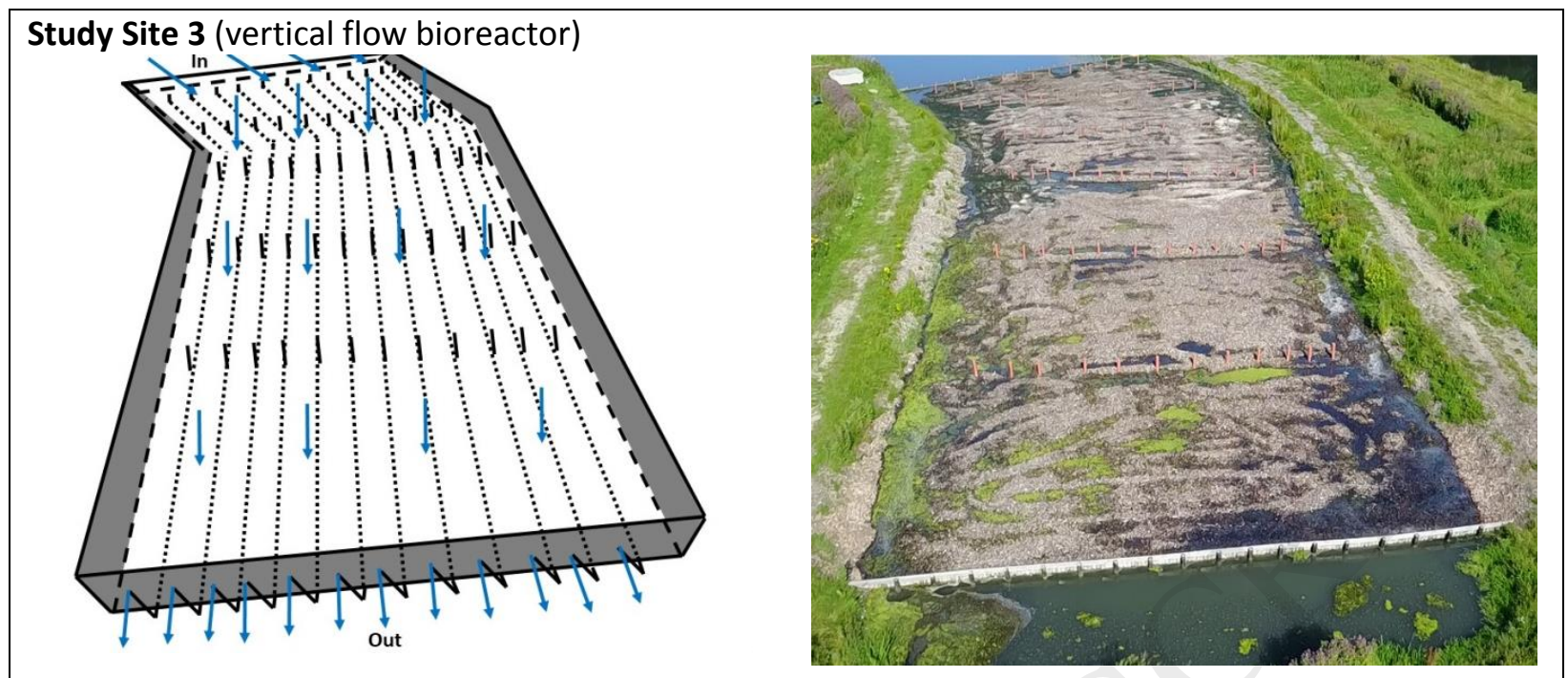

Figure 1. Study sites of three woodchip bioreactors located at commercial recirculated trout farms in Denmark: Conceptual drawings with theoretical flow scheme (left side) and site location photographs (right side). Drainage pipes are indicated by short dotted lines, and flow lines are represented by blue arrows. 
a)

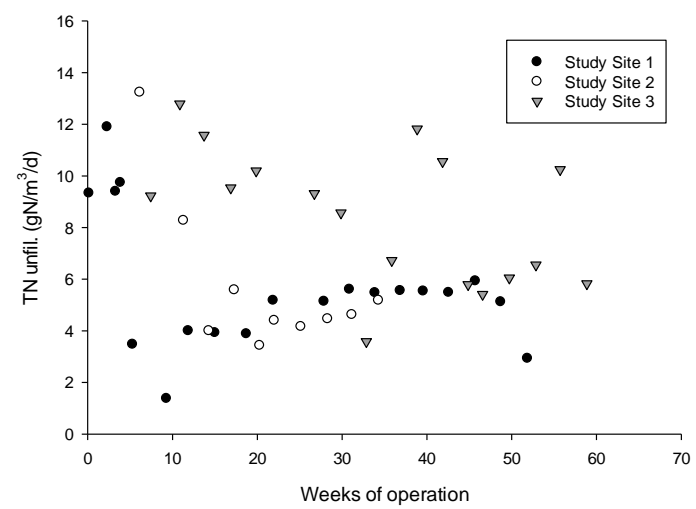

c)

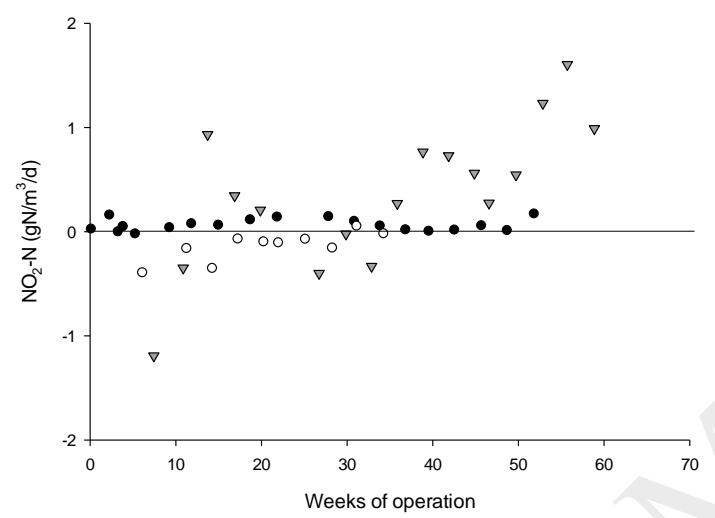

e)

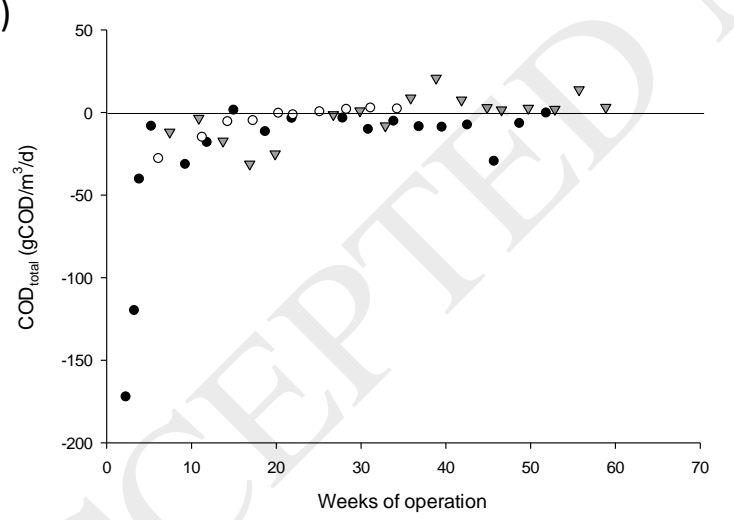

b)

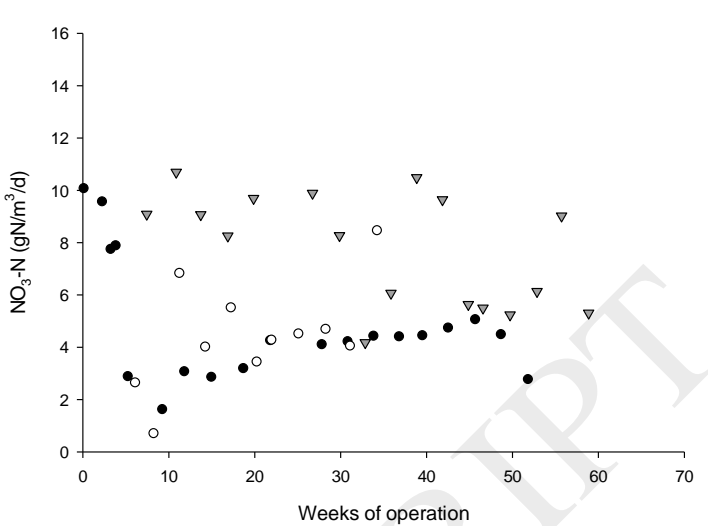

d)

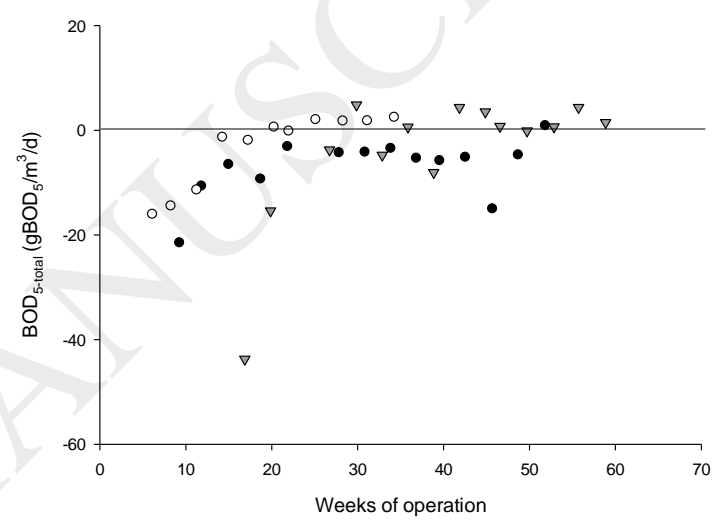

f)

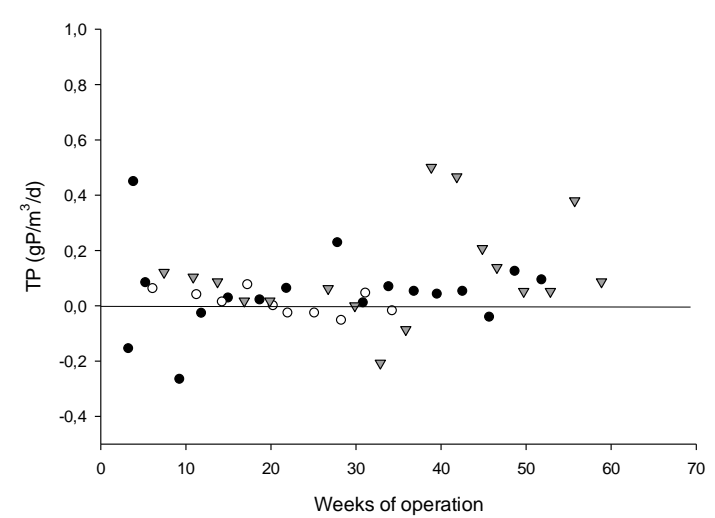


g)

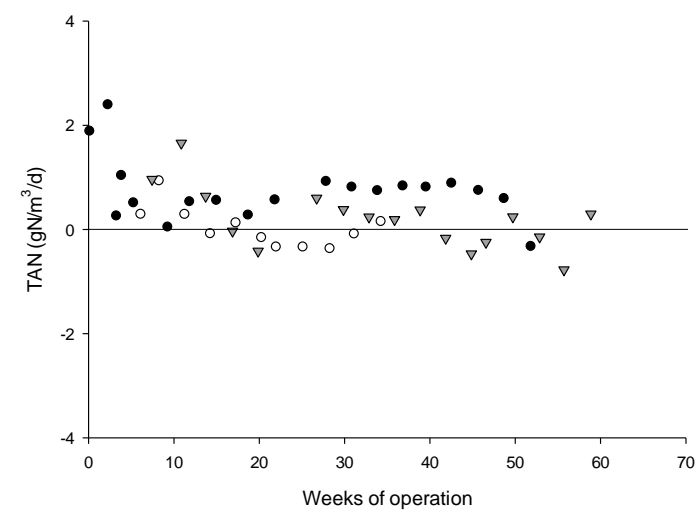

Figure 2. Removal rates (in $\mathrm{g} / \mathrm{m}^{3} / \mathrm{d}$ ) for different nutrients and organic matter plotted against weeks of woodchip bioreactor operation for three woodchip bioreactors (study sites 1-3) located at commercial recirculated trout farms in Denmark. 
Table

Table 1. Woodchip bioreactor specifications (mean \pm SD) for the three woodchip bioreactors at study sites 1-3 located at commercial recirculated trout farms in Denmark.

\begin{tabular}{|c|c|c|c|}
\hline & Study Site 1 & Study Site 2 & Study Site 3 \\
\hline $\begin{array}{l}\text { Start of woodchip bioreactor } \\
\text { operation }\end{array}$ & March 2017 & July 2017 & January 2017 \\
\hline Length $\mathrm{x}$ width $\mathrm{x}$ depth $(\mathrm{m})$ & $30 \times 10 \times 1$ & $30 \times 20 \times 1.1$ & $60 \times 20 \times 1.2$ \\
\hline Submerged woodchip volume $\left(\mathrm{m}^{3}\right)$ & 250 & 650 & 1250 \\
\hline $\begin{array}{l}\text { Effluent flow rate from fish } \\
\text { production unit }(\mathrm{L} / \mathrm{s})\end{array}$ & 25 & 30 & 30 \\
\hline $\begin{array}{l}\text { Inflow rate to woodchip } \\
\text { bioreactor (L/s) }\end{array}$ & $\begin{array}{c}3 \pm 2 \\
(n=19)\end{array}$ & $\begin{array}{l}12 \pm 4 \\
(n=11)\end{array}$ & $\begin{array}{l}25 \pm 4 \\
(n=17)\end{array}$ \\
\hline Average EBCT $(h)^{*}$ & $\begin{array}{c}26 \pm 13^{* *} \\
(\mathrm{n}=19)\end{array}$ & $\begin{array}{c}16 \pm 4 \\
(n=11)\end{array}$ & $\begin{array}{l}15 \pm 9 \\
(n=17)\end{array}$ \\
\hline $\begin{array}{l}\text { Average woodchip size }(\mathrm{cm}) \\
\text { (length } \mathrm{x} \text { width } \mathrm{x} \text { thickness) }\end{array}$ & $\begin{array}{c}2.1 \pm 0.3 \times 1.7 \pm 0.3 \\
\times 0.4 \pm 0.2 \\
(n=20)\end{array}$ & $\begin{array}{c}6.7 \pm 2.5 \times 2.7 \pm 2.1 \\
\times 0.7 \pm 0.4 \\
(n=20)\end{array}$ & $\begin{array}{c}7.6 \pm 2.5 \times 3.0 \pm 2.2 \\
\times 0.8 \pm 1.7 \\
(n=20)\end{array}$ \\
\hline Woodchip porosity (\%) & $\begin{array}{l}68 \pm 1 \\
(n=3)\end{array}$ & $\begin{array}{l}69 \pm 1 \\
(n=3)\end{array}$ & $\begin{array}{l}69 \pm 1 \\
(n=3)\end{array}$ \\
\hline Direction of water flow & horizontal & vertical, down flow & vertical, down flow \\
\hline
\end{tabular}

${ }^{*}$ Empty bed contact time $=$ volume of the submerged woodchips/flow rate

${ }^{* *}$ Calculated by taking into account that only $250 \mathrm{~m}^{3}$ of the total $350 \mathrm{~m}^{3}$ woodchips was submerged 
Table 2. Average inlet and outlet nutrient concentrations, five day biochemical oxygen demand $\left(\mathrm{BOD}_{5}\right)$, chemical oxygen demand (COD), and oxygen concentrations $(\mathrm{mg} / \mathrm{L})$ along with $\mathrm{pH}$ and temperature $\left({ }^{\circ} \mathrm{C}\right)$. In addition, average removal rates (RR; $\mathrm{g} / \mathrm{m}^{3} / \mathrm{d}$ ) are shown based on inlet and outlet concentrations and flow rates measured at the three woodchip bioreactors (study sites 1-3) located at commercial recirculated trout farms in Denmark. Average values are shown \pm standard deviation

\begin{tabular}{|c|c|c|c|c|c|c|c|c|c|}
\hline \multirow{2}{*}{ Parameter } & \multicolumn{3}{|c|}{$\begin{array}{l}\text { Study site } 1 \\
\quad(n=19)\end{array}$} & \multicolumn{3}{|c|}{$\begin{array}{l}\text { Study site } 2 \\
\quad(n=11)\end{array}$} & \multicolumn{3}{|c|}{$\begin{array}{c}\text { Study site } 3 \\
\quad(n=17)\end{array}$} \\
\hline & $\ln$ & Out & RR & $\ln$ & Out & RR & $\ln$ & Out & RR \\
\hline TN & $\begin{array}{c}6.9 \pm \\
0.2\end{array}$ & $\begin{array}{c}1.9 \pm \\
0.7\end{array}$ & $\begin{array}{c}5.7 \pm \\
2.5\end{array}$ & $\begin{array}{c}13.1 \pm \\
2.6\end{array}$ & $\begin{array}{c}9.8 \pm \\
2.2\end{array}$ & $\begin{array}{c}5.3 \pm \\
3.0\end{array}$ & $\begin{array}{r}13.1 \\
\pm 3.2\end{array}$ & $\begin{array}{c}8.2 \pm \\
2.9\end{array}$ & $\begin{array}{c}8.5 \pm \\
2.6\end{array}$ \\
\hline TN dissolved & $\begin{array}{c}6.8 \pm \\
0.2\end{array}$ & $\begin{array}{c}1.7 \pm \\
0.6\end{array}$ & $\begin{array}{c}6.0 \pm \\
3.0\end{array}$ & $\begin{array}{c}13.0 \pm \\
2.7\end{array}$ & $\begin{array}{c}9.8 \pm \\
2.1\end{array}$ & $\begin{array}{c}5.1 \pm \\
3.4\end{array}$ & $\begin{array}{r}12.7 \\
\pm 3.1\end{array}$ & $\begin{array}{c}7.8 \pm \\
2.8\end{array}$ & $\begin{array}{c}8.3 \pm \\
2.4\end{array}$ \\
\hline $\mathrm{NO}_{3}-\mathrm{N}$ & $\begin{array}{c}5.3 \pm \\
0.2\end{array}$ & $\begin{array}{c}1.0 \pm \\
0.5\end{array}$ & $\begin{array}{c}4.8 \pm \\
2.3\end{array}$ & $\begin{array}{c}10.5 \pm \\
3.5\end{array}$ & $\begin{array}{c}7.5 \pm \\
2.6\end{array}$ & $\begin{array}{c}4.5 \pm \\
1.9\end{array}$ & $\begin{array}{c}9.5 \pm \\
2.8\end{array}$ & $\begin{array}{c}4.9 \pm \\
2.5\end{array}$ & $\begin{array}{c}7.8 \pm \\
2.1\end{array}$ \\
\hline $\mathrm{NO}_{2}-\mathrm{N}$ & $\begin{array}{c}0.8 \pm \\
0.1\end{array}$ & $\begin{array}{c}0.0 \pm \\
0.0\end{array}$ & $\begin{array}{c}0.1 \pm \\
0.1\end{array}$ & $\begin{array}{c}0.3 \pm \\
0.1\end{array}$ & $\begin{array}{c}0.5 \pm \\
0.2\end{array}$ & $\begin{array}{c}-0.3 \pm \\
0.7\end{array}$ & $\begin{array}{c}0.7 \pm \\
0.3\end{array}$ & $\begin{array}{c}0.5 \pm \\
0.3\end{array}$ & $\begin{array}{c}0.4 \pm \\
0.7\end{array}$ \\
\hline TAN & $\begin{array}{c}1.0 \pm \\
0.3\end{array}$ & $\begin{array}{c}0.4 \pm \\
0.2\end{array}$ & $\begin{array}{c}0.7 \pm \\
0.6\end{array}$ & $\begin{array}{c}1.5 \pm \\
0.8\end{array}$ & $\begin{array}{c}1.5 \pm \\
0.8\end{array}$ & $\begin{array}{c}0.0 \pm \\
0.4\end{array}$ & $\begin{array}{c}2.2 \pm \\
0.6\end{array}$ & $\begin{array}{c}2.1 \pm \\
0.8\end{array}$ & $\begin{array}{c}0.2 \pm \\
0.6\end{array}$ \\
\hline $\mathrm{BOD}_{5 \text {-total }} * * *$ & $\begin{array}{c}3.2 \pm \\
0.8\end{array}$ & $\begin{array}{c}13.8 \pm \\
15.6\end{array}$ & $\begin{array}{c}-5.2 \pm \\
3.9\end{array}$ & $\begin{array}{c}3.0 \pm \\
1.2\end{array}$ & $\begin{array}{c}4.2 \pm \\
3.2\end{array}$ & $\begin{array}{c}2.0 \pm \\
0.3\end{array}$ & $\begin{array}{c}4.8 \pm \\
1.9\end{array}$ & $\begin{array}{c}7.4 \pm \\
6.9\end{array}$ & $\begin{array}{c}0.2 \pm \\
1.5\end{array}$ \\
\hline $\mathrm{BOD}_{5 \text {-diss }} * * *$ & $\begin{array}{c}2.4 \pm \\
0.8\end{array}$ & $\begin{array}{c}10.5 \pm \\
9.6\end{array}$ & $\begin{array}{c}-4.7 \pm \\
3.6\end{array}$ & $\begin{array}{c}2.5 \pm \\
1.6\end{array}$ & $\begin{array}{c}3.2 \pm \\
2.3\end{array}$ & $\begin{array}{c}1.4 \pm \\
0.6\end{array}$ & $\begin{array}{c}2.3 \pm \\
0.8\end{array}$ & $\begin{array}{c}4.1 \pm \\
4.5\end{array}$ & $\begin{array}{c}0.3 \pm \\
3.9\end{array}$ \\
\hline $\mathrm{COD}_{\text {total }} *$ & $\begin{array}{c}8.9 \pm \\
3.4\end{array}$ & $\begin{array}{c}40.2 \pm \\
50.1\end{array}$ & $\begin{array}{c}-8.9 \pm \\
7.9\end{array}$ & $\begin{array}{c}16.8 \pm \\
12.5\end{array}$ & $\begin{array}{r}17.5 \\
\pm 7.3\end{array}$ & $\begin{array}{c}2.2 \pm \\
0.3\end{array}$ & $\begin{array}{r}19.4 \\
\pm 5.6\end{array}$ & $\begin{array}{r}21.0 \\
\pm 7.8\end{array}$ & $\begin{array}{c}0.4 \pm \\
5.2\end{array}$ \\
\hline $\mathrm{COD}_{\text {diss }} *$ & $\begin{array}{c}6.8 \pm \\
1.3\end{array}$ & $\begin{array}{c}37.4 \pm \\
50.7\end{array}$ & $\begin{array}{c}-7.5 \pm \\
6.8\end{array}$ & $\begin{array}{c}15.7 \pm \\
10.4\end{array}$ & $\begin{array}{r}15.9 \\
\pm 5.5\end{array}$ & $\begin{array}{c}2.2 \pm \\
2.2\end{array}$ & $\begin{array}{r}14.0 \\
\pm 2.6\end{array}$ & $\begin{array}{r}17.0 \\
\pm 6.6\end{array}$ & $\begin{array}{c}4.3 \pm \\
7.2\end{array}$ \\
\hline TP & $\begin{array}{c}0.3 \pm \\
0.1\end{array}$ & $\begin{array}{c}0.3 \pm \\
0.4\end{array}$ & $\begin{array}{c}-0.2 \pm \\
0.7\end{array}$ & $\begin{array}{c}0.5 \pm \\
0.2\end{array}$ & $\begin{array}{c}0.4 \pm \\
0.2\end{array}$ & $\begin{array}{c}0.1 \pm \\
0.2\end{array}$ & $\begin{array}{c}0.6 \pm \\
0.3\end{array}$ & $\begin{array}{c}0.6 \pm \\
0.3\end{array}$ & $\begin{array}{c}0.1 \pm \\
0.2\end{array}$ \\
\hline $\mathrm{PO}_{4}-\mathrm{P}$ & $\begin{array}{c}0.2 \pm \\
0.0\end{array}$ & $\begin{array}{c}0.2 \pm \\
0.2\end{array}$ & $\begin{array}{c}-0.1 \pm \\
0.5\end{array}$ & $\begin{array}{c}0.4 \pm \\
0.2\end{array}$ & $\begin{array}{c}0.4 \pm \\
0.2\end{array}$ & $\begin{array}{c}0.1 \pm \\
0.1\end{array}$ & $\begin{array}{c}0.3 \pm \\
0.2\end{array}$ & $\begin{array}{c}0.3 \pm \\
0.2\end{array}$ & $\begin{array}{c}0.0 \pm \\
0.1\end{array}$ \\
\hline Dissolved $\mathrm{O}_{2}$ & $\begin{array}{c}9.0 \pm \\
0.5\end{array}$ & $\begin{array}{c}0.4 \pm \\
0.2\end{array}$ & - & $\begin{array}{c}3.2 \pm \\
0.5\end{array}$ & $\begin{array}{c}0.8 \pm \\
0.3\end{array}$ & - & $\begin{array}{c}1.9 \pm \\
1.6\end{array}$ & $\begin{array}{c}0.4 \pm \\
0.2\end{array}$ & - \\
\hline $\mathrm{pH}$ & $\begin{array}{c}7.2 \pm \\
0.2\end{array}$ & $\begin{array}{c}7.0 \pm \\
0.3\end{array}$ & - & $\begin{array}{c}7.4 \pm \\
0.2\end{array}$ & $\begin{array}{c}7.3 \pm \\
0.2\end{array}$ & - & $\begin{array}{c}7.5 \pm \\
0.1\end{array}$ & $\begin{array}{c}7.2 \pm \\
0.2\end{array}$ & - \\
\hline Temperature & $\begin{array}{r}10.0 \\
\pm 3.2\end{array}$ & $\begin{array}{c}10.0 \pm \\
3.3\end{array}$ & - & $\begin{array}{c}9.9 \pm \\
3.2\end{array}$ & $\begin{array}{c}9.8 \pm \\
3.4\end{array}$ & - & $\begin{array}{r}10.5 \\
\pm 3.3\end{array}$ & $\begin{array}{r}10.5 \\
\pm 3.3\end{array}$ & - \\
\hline
\end{tabular}


*Average removal rates of $\mathrm{BOD}_{5 \text {-total, }} \mathrm{BOD}_{5 \text {-diss, }} \mathrm{COD}_{\text {total }}$ and $\mathrm{COD}_{\text {diss }}$ are averages of measurements taken after the first 26 weeks of operation.

**The number of measurements $(\mathrm{n})$ for analyses of $\mathrm{BOD}_{5 \text {-total }}$ and $\mathrm{BOD}_{5 \text {-diss }}$ after the first 26 weeks of operation were 9 for study sites 1 and 3 , and 4 for study site 2 . 